
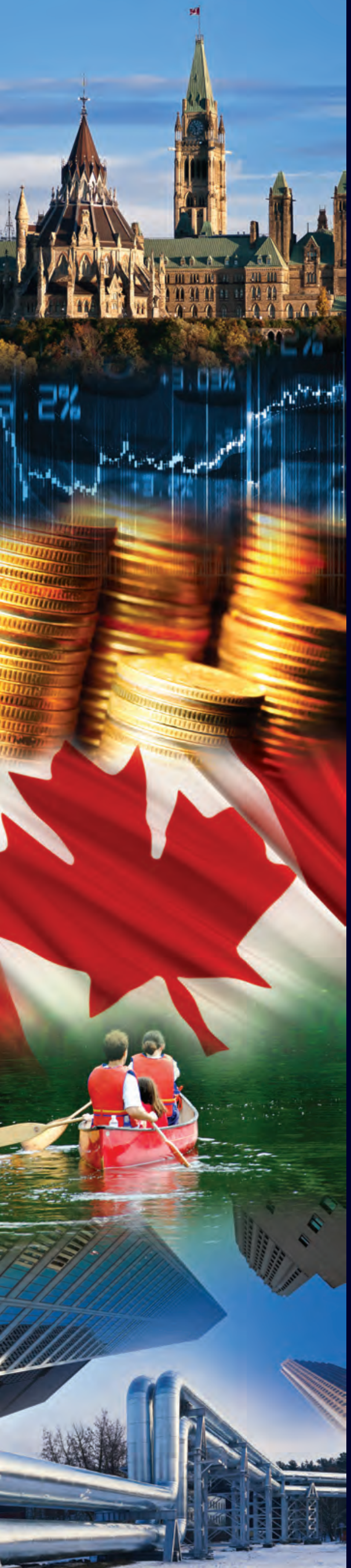

institut C.D. HOWE institute

COMMENTARY

NO. 434

\title{
Value for Money? \\ Teacher Compensation and Student Outcomes in Canada's Six Largest Provinces
}

Do provinces that pay their teachers more achieve better results in student achievement?

David R. Johnson 


\section{THE INSTITUTE'S COMMITMENT TO QUALITY}

\section{ABOUT THE AUTHOR}

David R. Johnson

is Professor of Economics, Wilfrid Laurier University.
Commentary No. 434

September 2015

Education Policy
C.D. Howe Institute publications undergo rigorous external review by academics and independent experts drawn from the public and private sectors.

The Institute's peer review process ensures the quality, integrity and objectivity of its policy research. The Institute will not publish any study that, in its view, fails to meet the standards of the review process. The Institute requires that its authors publicly disclose any actual or potential conflicts of interest of which they are aware.

In its mission to educate and foster debate on essential public policy issues, the C.D. Howe Institute provides nonpartisan policy advice to interested parties on a non-exclusive basis. The Institute will not endorse any political party, elected official, candidate for elected office, or interest group.

As a registered Canadian charity, the C.D. Howe Institute as a matter of course accepts donations from individuals, private and public organizations, charitable foundations and others, by way of general and project support. The Institute will not accept any donation that stipulates a predetermined result or policy stance or otherwise inhibits its independence, or that of its staff and authors, in pursuing scholarly activities or disseminating research results.
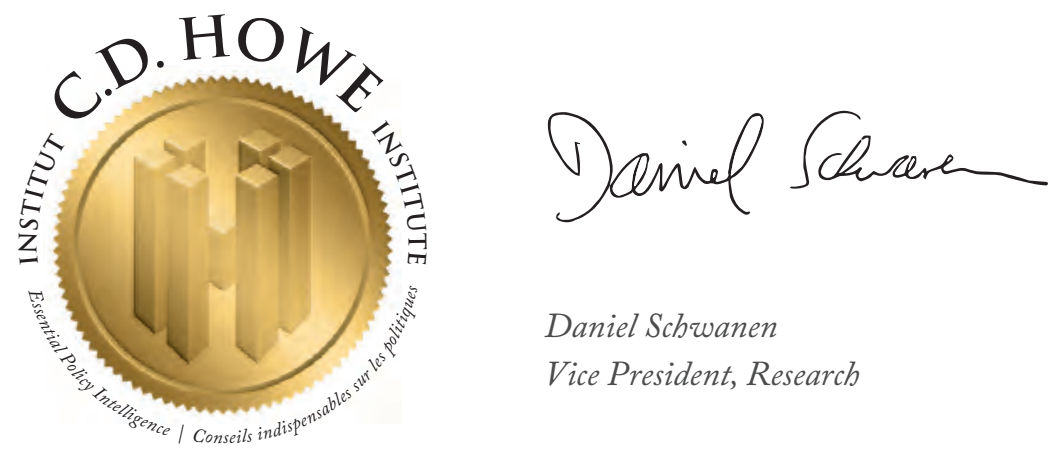

Daniel Schwanen

Vice President, Research 


\section{THE STUDY IN BRIEF}

Teacher salaries must be attractive enough to draw proficient persons into the profession that deliver positive results in classrooms. But how much do teachers in publicly funded school systems earn relative to the overall population? And do provinces that pay their teachers more achieve better student results?

This paper compares teacher salaries in Canada's six largest provinces to wages of other similar workers. Manitoba and Ontario pay the most relative to other similar workers in the province, while British Columbia teacher wages are usually the lowest. Relative salaries in Alberta and Saskatchewan are closer to those in British Columbia than those in Ontario or Manitoba. Pension benefits are also generally most generous in Manitoba and Ontario and least generous in British Columbia.

The study finds no clear relationship between province-wide student assessment results and relative teacher compensation. So despite considerably lower levels of overall relative compensation, British Columbia and the other three provinces with similar relative compensation levels attract teachers who produce comparable outcomes.

Provinces that desire to limit growth in overall public expenditures, and that are home to relatively wellcompensated teachers, appear to have negotiating room to limit the growth of teacher compensation relative to other occupations. It is unrealistic to expect that such a compensation change could occur quickly. Relative salaries could be reduced gradually by having a series of wage settlements where increases are less than the rate of inflation. To emulate the pension rules in British Columbia, pension generosity in other provinces could also be adjusted gradually. The evidence suggests that even at British Columbia's levels of relative salaries and pensions, proficient persons are attracted to the profession.

C.D. Howe Institute Commentary $(\mathrm{C}$ is a periodic analysis of, and commentary on, current public policy issues. Michael Benedict and James Fleming edited the manuscript; Yang Zhao prepared it for publication. As with all Institute publications, the views expressed here are those of the author and do not necessarily reflect the opinions of the Institute's members or Board of Directors. Quotation with appropriate credit is permissible.

To order this publication please contact: the C.D. Howe Institute, 67 Yonge St., Suite 300, Toronto, Ontario M5E 1J8. The full text of this publication is also available on the Institute's website at www.cdhowe.org. 


\section{Teacher salaries are often the subject of discussion, both among the general public and in the political arena. Compared to other workers, even workers with the same education level, public school teachers earn relatively high salaries and have generous benefits, pensions and holidays.}

However, a more important issue is not what teachers are paid but whether their salaries are attractive enough to draw proficient persons into the profession; persons that deliver positive results in classrooms. Education costs are the secondlargest spending item in provincial budgets, behind healthcare, and more than 90 percent of primary and secondary students are enrolled in public schools. In this Commentary, I look at teacher compensation in elementary and secondary publicly funded schools across Canada's six most populous provinces and ask, "Do provinces that pay their teachers more achieve better results?"

There is significant variation in teacher salaries in these provinces - Ontario, Quebec, British Columbia, Alberta, Manitoba and Saskatchewan. Manitoba and Ontario pay the most relative to other employees in their own province, while BC teacher wages are usually the lowest in relative terms. Although Alberta teachers are paid the most in absolute terms, they work in a province where other employees are also better remunerated.

In examining comparable academic assessments of teacher salaries and student achievement in these six Canadian provinces, I have come to this conclusion: there is no clear relationship between province-wide student results and relative teacher pay. For example, BC students, whose public school teachers have among the lowest relative salaries, generally achieve the same or better academic results as students in other provinces.

These findings suggest that factors other than high salaries and attracting stronger candidates into teaching play an important role in achieving better results. Indeed, the slightly better student achievement results (they are only slightly better and often not statistically different) in British Columbia and Alberta might lead policymakers to ask what other factors play a role in those provinces. The menu of possibilities is quite large. Richards et al. (2008) and Richards (2014) show that British Columbia handles its Aboriginal students differently than other provinces and gets more positive outcomes. Friesen et al. (2015) make the argument that open enrolments at schools and the ensuing competition for students in British Columbia could be an important factor in attaining these better results.

In Edmonton, Johnson (2014) places particular emphasis on how the broad introduction of school choice led to improved overall academic results in the city's schools - public, separate and private. This argument could extend to the rest of Alberta to some degree.

Among the many policies and unique characteristics that may explain the differences in

The author thanks several anonymous reviewers, discussants at the 2015 meetings of the Canadian Economics Association, as well as Benjamin Dachis and Colin Busby of the C.D. Howe Institute for comments on earlier drafts of this paper. He retains responsibility for any remaining errors and the views expressed here. 
student assessment results across the provinces, this Commentary eliminates only the argument that paying teachers more is associated with better student performance. The policy implication is clear: provinces that are paying higher salaries have room to slow the growth of teacher compensation relative to other occupational categories, perhaps over a long period of time, without reducing the level of student achievement results.

This answer to my first policy question ("Do provinces that pay their teachers more achieve better results?") leads logically to a second question: Are there factors that could help us understand why teacher salaries are higher in some provinces than others? One potential answer lies in a better understanding of how provinces negotiate salaries with unionized teachers. For example, Manitoba, with relatively high teacher salaries, also has no centralized bargaining.

British Columbia, Saskatchewan and, to a lesser extent, Quebec, have the longest history of centralized, provincial-level bargaining, and their teachers clearly earn lower relative salaries in this set of six provinces. This suggests that centralized bargaining between teachers and the provincial education ministry instead of board-by-board negotiations could be related to lower relative salaries, perhaps influencing Alberta and Ontario in making their slow transition from local to full provincial bargaining. Meanwhile, the resistance of teachers' unions to centralized provincial bargaining is consistent with the observation that the provinces with the longest history of centralized bargaining have the lowest relative levels of teacher compensation.
However, there is an important cautionary note to this proposition. Manitoba, with the weakest role for centralized bargaining, is also the only province in these six provinces where teachers do not have the right to strike and salary disputes are arbitrated. Therefore, higher relative teacher salaries in Manitoba could either be the result of local bargaining, salary arbitration, or some combination of the two factors.

\section{TEACHER SALARIES ACROSS PROVINCES}

Teachers in five of the six provinces are paid according to a salary grid reflecting education level, at least loosely, and experience. In Quebec, the grid is based only on seniority with the starting point depending on qualifications.

In all provinces, teachers inside one pay category move to the next pay level with experience. A typical grid has four to six categories, with the grid ending at 10 or 11 years of experience. ${ }^{1}$ The remainder of a teacher's career is at the category's highest salary point. If the teacher is not in the highest category, he or she can often take action to move up a category.

Table 1 presents two top categories from each province's salary grid. However, it is difficult to determine precisely what proportion of teachers fall into each category and which categories are comparable across provinces. I used the British Columbia Teachers' Federation (BCTF) analysis in choosing equivalent teachers across provinces. ${ }^{2}$ Quebec has only one pay category. Meanwhile, the vast majority of teachers in British Columbia,

1 The online Appendix presents details on the construction of these grids. Quebec is the exception with its 17-“year” grid, although most teachers start at Steps 5,6 or 7 so the actual movement is over 10 to 12 years.

2 To quote BCTF (2014), "The categories chosen as the most suitable matches are based on information on teacher certification qualifications available online for each province or territory." I have extended the formal analysis in the online Appendix to include the third-highest pay category in Alberta and Saskatchewan because a significant percentage of teachers in those provinces fall into this group, a cohort excluded from the BCTF comparison. 


\section{Table 1: Teacher Salaries (2013/2014)}

\begin{tabular}{|c|c|c|c|c|c|c|}
\hline Level (Rank) & \multicolumn{6}{|c|}{$\begin{array}{c}\text { Highest Pay Category } \\
\text { Current Dollars (2013/2014) }\end{array}$} \\
\hline & BC & Alberta & Saskatchewan & Manitoba & Ontario & Quebec \\
\hline Highest & $81,534(5)$ & $99,112(1)$ & 88,347 (4) & $94,466(2)$ & $91,815(3)$ & $75,729(6)$ \\
\hline Entry & $51,244(5)$ & $66,690(1)$ & $57,952(3)$ & $62,099(2)$ & $52,954(4)$ & $49,940(6)$ \\
\hline Level (Rank) & \multicolumn{6}{|c|}{$\begin{array}{l}\text { Second-Highest Pay Category } \\
\text { Current Dollars (2013/2014) }\end{array}$} \\
\hline Province & $\mathrm{BC}$ & Alberta & Saskatchewan & Manitoba & Ontario & Quebec \\
\hline Highest & $74,353(6)$ & $95,284(1)$ & $83,584(4)$ & $84,517(3)$ & $85,798(2)$ & $75,729(5)$ \\
\hline Entry & $46,597(6)$ & $61,419(1)$ & $54,393(2)$ & $55,318(3)$ & $49,632(5)$ & $49,940(4)$ \\
\hline
\end{tabular}

Source: Author's calculations as described in text and online Appendix.

Ontario and Manitoba fall into the two top pay categories. The situation in Alberta is less clear.

In Ontario, three-quarters of teachers fall into the highest pay category, while the majority of Manitoba and $\mathrm{BC}$ teachers fall into the second-highest pay category. About one-half of Saskatchewan teachers fall into the third-highest pay category, which does not appear in Table 1. (A similar third-highest pay category exists in Alberta. ${ }^{3}$ ) This means the average teacher salary in Saskatchewan and Alberta may be slightly less than those listed in Table 1, a fact that strengthens the central argument of this Commentary that higher relative teacher salaries are not strongly related to better student performance.

Two provinces, Quebec and Saskatchewan, have province-wide salary grids: all teachers with the same years of experience in the same category (there is only one category in Quebec) receive the same salary. In the other provinces where teachers are paid varying amounts among boards, I collected salary data from the largest boards so that the salaries I calculate cover the teachers of more than 50 percent of that province's students.

3 Information I received from one large Alberta public school board indicated the third-highest pay category covered about 50 percent of its teachers. It may or may not be the case that the distribution of teachers by salary category in this board is representative of the province as a whole. 
Table 1 also presents salaries at the entry point and at the maximum point for the two highest-pay categories. The provinces move up and down the salary rankings depending on the pay category and whether one measures salaries at entry or at the maximum level. However, there is a more useful way to measure teacher salaries and compare them across provinces - relating them to the earnings of non-teacher employees.

\section{PLACING TEACHERS IN THE EARNINGS DISTRIBUTION WITHIN THEIR OWN PROVINCE}

In my comparison analysis, I place the salaries of teachers in the 2013/14 academic year within the earnings distribution of all other full-time, single-job employees and then of all other fulltime, single job employees who have a bachelor's degree and who are not teachers or professors. ${ }^{4}$ The comparisons rely on Labour Force Survey (LFS) data from October 2013 and April 2014. ${ }^{5}$

The LFS reports individual data by age categories: 25 to $26 ; 27$ to 29 and then by fiveyear age intervals. It also reports each individual's highest education level. I assume that teachers start full-time work at age 25 and move through the salary grid, adding one year of experience for each year of age. ${ }^{6}$ I assign the first and second year of each provincial teacher's salary grid to a person aged 25 and 26. I do the same by assigning years 3, 4 and 5 to a person aged 27, 28 and 29. I then assign the remaining years of the grid to teachers of the relevant age.

The LFS comparator earnings by age group are averages that correspond to the relevant years in the teachers' grid. Because all earnings, not just salaries of teachers, are strongly related to age and experience, it is important to make these comparisons age specific. I am able to present the earnings of a teacher as a percentile of earnings of others of comparable age and, eventually, with comparable level of education in Tables 2 and $3 .^{7}$

\section{A comparison of teacher salaries with earnings of all employees}

BC teachers on entry, aged 25 to 26 , in the secondhighest pay category earn an average salary of $\$ 47,000$. This salary then grows as they gain experience. If we use the early part of their teaching career from ages 25-39, within British Columbia as a whole roughly 71 percent of single-job, full-time employees aged 25 to 39 earn less than a teacher. Therefore from ages 25 to $39, \mathrm{BC}$ teachers are at the $71^{\text {st }}$ percentile of earnings (Table 2). Clearly, the

4 The Organisation for Economic Cooperation and Development (OECD 2014a) presents similar international comparisons of teacher salaries as a ratio to average salaries of all other full-time, full-year workers with tertiary education. It also presents teacher salaries as a ratio to per capita GDP. Using either metric, Canadian teachers are very well compensated compared to their OECD counterparts.

5 The LFS data contain individual information on hourly wages, usual weekly hours and employment status as well as on age and education.

6 I recognize that many people entering the teaching profession spend time first as supply or substitute teachers and that this period of time can be lengthy in some provinces. In a sense, this reinforces the argument that the characteristics, salary and otherwise of a full-time permanent teaching job are so appealing that people are willing to take a less secure, supplyteaching job for a considerable period of time while waiting to obtain a full-time position.

7 My approach is similar to that taken in Leonard and Sweetman (2014) who use Census data to look at the distribution of earnings of healthcare workers relative to non-healthcare workers. 


\section{Table 2: Teacher Salaries as Average Percentile of Salaries among All Earners}

\begin{tabular}{|c|c|c|c|c|c|c|}
\hline Level & & & Highest Pay Cat & ry $(2013 / 20$ & & \\
\hline Province & $\mathrm{BC}$ & Alberta & Saskatchewan & Manitoba & Ontario & Quebec \\
\hline Aged 25-39 & 78 & 81 & 77 & 93 & 83 & 83 \\
\hline Aged 40-60 & 83 & 82 & 84 & 94 & 86 & 87 \\
\hline All Ages & 81 & 81 & 81 & 93 & 85 & 85 \\
\hline Level & & & nd-Highest Pay & tegory (2013 & & \\
\hline Province & $\mathrm{BC}$ & Alberta & Saskatchewan & Manitoba & Ontario & Quebec \\
\hline Aged 25-39 & 71 & 78 & 73 & 87 & 79 & 83 \\
\hline Aged 40-60 & 75 & 80 & 81 & 90 & 82 & 87 \\
\hline All Ages & 73 & 79 & 78 & 89 & 81 & 85 \\
\hline
\end{tabular}

Source: Author's calculations as described in text and online Appendix.

higher the position in the earnings distribution, the more attractive is a teaching job relative to other jobs, all other factors being equal.

$\mathrm{BC}$ teachers' earnings relative to other earnings in the province rise slightly to the $75^{\text {th }}$ percentile between the ages of 40 and 60 when this teacher is in the second-highest pay category. Over their careers, $\mathrm{BC}$ teachers in the second-highest pay category - the most common category - have average earnings in the $73^{\text {rd }}$ percentile as shown in Table 2. This is the lowest value among the second-highest paid teacher categories in the six provinces. In Manitoba, for example, the salaries of the second-highest pay category are at the $89^{\text {th }}$ percentile of all earnings.

Table 2 also looks at the highest-paid category of teachers in each province. Except for Quebec, the percentile values are higher than for the second-highest paid group. In British Columbia, for example, the highest paid teacher earns in the $81^{\text {st }}$ percentile of all employees. In Alberta and Saskatchewan, the percentile is the same. Meanwhile, the highest-paid teachers in Manitoba, Ontario and Quebec are in the $85^{\text {th }}$ and $93^{\text {rd }}$ percentiles. 
As already noted, roughly 75 percent of Ontario's teachers are in the highest pay category. In Manitoba, the second-highest pay category covers about 50 percent of teachers. ${ }^{8}$ Meanwhile, it appears that about one-half of Saskatchewan's and perhaps up to one-half of Alberta's teachers fall into pay categories below the second-highest pay category. These categories are not considered comparable by the British Columbia Teachers' Federation, on whose analysis I partly rely to establish comparable categories (BCTF 2014). As a result of excluding those cohorts, those two provinces' highest two pay categories do slightly exaggerate the actual salary percentiles of Alberta and Saskatchewan teachers. ${ }^{9}$

The conclusion from Table 2 is that teachers in Manitoba, Ontario and Quebec are relatively better paid than teachers in British Columbia, Alberta and Saskatchewan when the comparison is to all other full-time single-job employees.

\section{A comparison of teacher salaries with earnings of other holders of bachelor degrees}

Table 3 compares the top two teacher pay categories with the earnings of other employees with a bachelor's degree who are not teachers (or professors). Arguably, this is a better comparison group than with the overall population. Since persons with degrees are typically paid more, the percentiles of teacher salaries fall when other full-time single-job non-teacher employees with a bachelor's degree are used as the comparison group. ${ }^{10}$

In this exercise, the relative ranking across provinces changes slightly. BC teachers earn the lowest relative salaries. Ontario and Manitoba teachers earn the highest. Relative salaries appear to be fairly similar across the other three provinces. There is the very important caution that 50 percent of teachers in Saskatchewan and a significant group of teachers in Alberta earn less than the two categories in Table 3. Including them would reduce salary percentiles of teachers in those provinces.

\section{Lessons from placing teacher salaries in earnings percentiles}

Relative to other full-time employees, teachers at all ages fall into relatively high-earnings percentiles. Almost all entries in Table 2 are in the $80^{\text {th }}$ percentile or higher. ${ }^{11}$ The lowest entry is 71 for $\mathrm{BC}$ teachers when young.

In Manitoba, the highest and second-highest paid categories of teachers are very well paid relative to other workers in that province $\left(87^{\text {th }}\right.$ to $94^{\text {th }}$ percentiles) and relative to teachers in other provinces. Meanwhile, BC teachers in the secondhighest pay category fall into the low 70s, while many of their counterparts in other provinces are in the 80 s or, in Manitoba, even the 90s.

8 In Manitoba, what is labelled here as the second-highest pay category is actually the third-highest. This small anomaly is a result of using the BCTF (2014) pay categories.

9 I re-emphasize that BCTF (2014) made the choice of comparable teacher categories used in this study. A separate research project would be required to better understand the issues around variation in teacher classifications across provinces. The online Appendix uses salary percentiles from an estimate of the most common category of teachers in each province.

10 The percentiles are very similar if the comparator group is all persons with any completed university degree including teachers and professors.

11 The available data do not allow one to compare the value of benefits in a teacher contract to those for other full-time, single-job employees. The only available comparison is earnings on an annual basis. I am assuming that variation in teaching time, preparation time outside teaching hours, participation in extracurricular leadership and number of teaching days is relatively small across provinces. 


\section{Table 3: Teacher Salaries as Average Percentile of Salaries of Non-teachers with Bachelor's Degree}

\begin{tabular}{|c|c|c|c|c|c|c|}
\hline Level & & & Highest Pay Ca & ry $(2013 / 20$ & & \\
\hline Province & $\mathrm{BC}$ & Alberta & Saskatchewan & Manitoba & Ontario & Quebec \\
\hline Aged 25-39 & 71 & 76 & 70 & 88 & 76 & 76 \\
\hline Aged 40-60 & 71 & 70 & 76 & 89 & 78 & 67 \\
\hline All Ages & 71 & 73 & 73 & 89 & 77 & 71 \\
\hline Level & & & nd-Highest Pay & tegory (201: & & \\
\hline Province & $\mathrm{BC}$ & Alberta & Saskatchewan & Manitoba & Ontario & Quebec \\
\hline Aged 25-39 & 65 & 71 & 65 & 79 & 72 & 76 \\
\hline Aged 40-60 & 63 & 69 & 73 & 82 & 73 & 67 \\
\hline All Ages & 64 & 70 & 70 & 81 & 72 & 71 \\
\hline
\end{tabular}

Source: Author's calculations as described in text and online Appendix.

In Ontario, the vast majority of teachers earn between the 83rd and 86th percentile of earnings for all employees. Actual Ontario teacher salaries are therefore at a considerably higher percentile than the second-highest paid teachers in Alberta, Saskatchewan and British Columbia. This is partly because 75 percent or more of Ontario's teachers are in the highest pay category in Ontario. These gaps are even wider if one includes the roughly 50 percent of teachers in the third-highest pay category in Saskatchewan and a smaller but still significant group of those teachers in Alberta in the third-highest pay category. ${ }^{12}$

Even when we move to Table 3 and use a comparator group where all employees have at least a bachelor's degree, there is a range of

12 The comparison of teacher salaries that includes the third-highest pay group is found in the online Appendix. 
relative salaries across provinces with Manitoba, in particular, and Ontario in the lead - keeping in mind that 75 percent of Ontario's teachers are in the highest pay category.

\section{A comparison of teacher pension plans across the six provinces}

An important part of one's lifetime compensation stream is the pension arrangement. How similar are they across these six provinces? And if they are different, are the more generous plans found in provinces where salaries are lower?

The plans appear quite similar. All teachers have a defined-benefit plan with a formula-based pension at exit. ${ }^{13}$ The plans have similar levels of inflation protection, usually some form of partial indexation. In some provinces, teachers who retired long ago even qualify for full inflation protection.

One substantial difference among the six plans is the time to qualify for a full pension without a reduction in benefits. $\mathrm{BC}$ teachers have the least generous formula to qualify - age plus years of service must total 90. Manitoba teachers have the most generous formula - age plus years of service must add up only to 80. Alberta, Saskatchewan and Ontario all use 85 as the qualifying factor. Quebec applies a more complicated formula in which the eligibility rule seems to fall between the 85 and 90 factors.

Pension contribution rates also vary substantially across the six provinces. BC and Alberta teachers make the largest employee contributions. Manitoba teachers make the smallest. As a result, the province with the highest relative salaries, Manitoba, also has the most generous pension plan while British Columbia, with the lowest relative salaries, has the least generous pension.

\section{RELATIVE SALARIES AND ACADEMIC RESULTS}

Given the substantial variation in teacher compensation across these six provinces, it raises the question whether provinces where teachers are better compensated attract higher quality teachers who would be expected to produce better academic results.

Among the most common measurable student education outcomes are proficiency in reading, mathematics and science. ${ }^{14}$ Two such measures are available in all provinces. One is the 2012 Program for International Student Assessment (PISA). PISA measures the outcomes in reading, mathematics and science for 15-year old students in a large number of countries across the world. Table 4 presents the average PISA results by province. ${ }^{15}$

In the online Appendix, I use the second outcome measure, results from the Pan-Canadian Assessment Program (PCAP). PCAP measures outcomes in science, reading and mathematics as of Grade 8. PISA and PCAP are similar but not identical.

Making use of the international variation in PISA results, some researchers have argued there should be a positive relationship with

13 The usual formula takes years of service multiplied by 2 percent and multiplying that result by an average of the individual's five highest salary levels. There is usually a cap on the amount.

14 Other possible measures could be the dropout rate or average educational attainment. The results I use are found in OECD (2012).

15 In many cases, average results across provinces are not statistically different from each other. That is the point of this Commentary, in many or most cases provincial results on various assessments are quite similar while teachers' relative compensation varies by considerable amounts. 


\section{Table 4: Average 2012 PISA Assessments}

\begin{tabular}{|l|c|c|c|c|c|c|}
\hline $\begin{array}{l}\text { Assessment } \\
\text { (result better than } \\
\text { these provinces })\end{array}$ & BC & Alberta & Saskatchewan & Manitoba & Ontario & Quebec \\
\hline Mathematics & $\begin{array}{c}527 \\
(\mathrm{SK}, \mathrm{MB})\end{array}$ & $\begin{array}{c}517 \\
(\mathrm{SK}, \mathrm{MB})\end{array}$ & 502 & 493 & $\begin{array}{c}522 \\
(\mathrm{SK}, \mathrm{MB})\end{array}$ & $\begin{array}{c}530 \\
(\mathrm{SK}, \mathrm{MB})\end{array}$ \\
\hline Reading & $\begin{array}{c}542 \\
(\mathrm{SK}, \mathrm{MB}, \\
\mathrm{QC})\end{array}$ & $\begin{array}{c}529 \\
(\mathrm{SK}, \mathrm{MB})\end{array}$ & 511 & 503 & 534 & 520 \\
\hline Science & $\begin{array}{c}544 \\
(\mathrm{SK}, \mathrm{MB}, \\
\mathrm{ONN}, \mathrm{QC})\end{array}$ & $\begin{array}{c}539 \\
(\mathrm{SK}, \mathrm{MB}, \\
\mathrm{QC})\end{array}$ & $\begin{array}{c}516 \\
(\mathrm{MB})\end{array}$ & 503 & $\begin{array}{c}527 \\
(\mathrm{MB})\end{array}$ & 516 \\
\hline
\end{tabular}

Note: A province is stated as having better results than another province when its 95 percent lower bound exceeds the 95 percent upper bound of another province. Standard errors are found in Figures 1,2 and 3 as bars around average results.

Source: Brochu et al. (2013).

teacher compensation. If teachers are very well compensated within a country relative to other jobs, better candidates within that country are attracted to the profession. With better teachers, on average, academic results should be better, or so the theory goes.

Indeed, Dolton and Marcenaro-Gutierrez (2011) claim to show a positive relationship between salaries and PISA results in some countries when they place teacher salaries (measured in comparable real units of purchasing power) on one axis of a graph and PISA results on the other. Their findings are used to make the rather vivid argument that, "If you pay peanuts, you do get monkeys." Low pay equals poorer teachers in their analysis.

OECD (2014b, p. 27) provides a similar diagram with a larger sample of countries. Using the OECD graph, depending on the group of countries in the sample, there is a positive relationship between average teacher salaries (expressed as a ratio of teacher salary to per capita Gross Domestic Product) and PISA results. There is a specific claim in OECD (2013, p. 43) that the relationship is stronger between relative teacher salaries and mathematics results.

This analysis of international results has generated considerable discussion. The OECD (2014b, p. 26) argues: "Higher salaries can help school systems to attract the best candidates to the teaching profession. PISA results show that, among countries and economies whose per capita GDP is more than US $\$ 20,000$, high-performing school systems tend to pay more to teachers relative to their national income per capita." This argument is also made on behalf of the Canadian Teachers Federation by Ellis and Myles (2013). These conclusions are partially supported by Akiba et al. (2012) who find that while the average starting salary of secondary school teachers had no influence on PISA results, the higher salaries of more experienced teachers had a positive influence. For his part, Woessmann (2011) has, in some specifications, also found a positive association between teacher salary levels and PISA outcomes, 
although his major focus is on the positive relationship between better PISA outcomes and teacher performance pay. ${ }^{16}$

However, the Canadian story is different. Figures $1 \mathrm{a}, 1 \mathrm{~b}, 2 \mathrm{a}$ and $2 \mathrm{~b}$ are plots of relative teacher salaries and PISA results in our six provinces. Figures $1 \mathrm{a}$ and $1 \mathrm{~b}$ use the percentile of teacher salaries compared to the earnings of all employees. Figures $2 \mathrm{a}$ and $2 \mathrm{~b}$ use the percentile of teacher salaries compared to other employees with a bachelor's degree excluding teachers and professors. In the figures, I break out the results for the secondhighest pay (Figures 1a and 2a) and the highest-pay categories (Figures $1 \mathrm{~b}$ and $2 \mathrm{~b}$ ). Both sets of figures demonstrate that there is no obvious relationship between high-salary percentile teacher earnings and better PISA academic results. If higher relative salaries attracted better teachers, this relationship should be positive.

The vertical lines in the Figures include standard error bands around each mean for each test. If the standard error bands overlap, provinces are statistically tied in results. British Columbia, Alberta, Ontario and Quebec are often tied in their PISA results, when potential statistical errors are considered. Scores in these four provinces typically surpass those in Manitoba and Saskatchewan. Details for the average PISA scores of 15-year-olds in the figures are presented in Table $4 .^{17}$

Across these six provinces, the reality is that paying teachers relatively more is not associated with better results. Manitoba, while paying in the highest percentiles for the categories explored here, has the lowest PISA results. British Columbia, which tends to have the lowest-paid teachers, tends to have somewhat better results than other provinces. Across provinces, there is a wide percentile range of salaries; about five to 10 points.

Still, before we make more of the seemingly non-existent relationship in Canada between higher salaries and better results, there are two cautionary notes.

\section{Provincial demographics and academic performance}

One very obvious social and economic difference among these six provinces is the percentage of Aboriginals. ${ }^{18}$ Saskatchewan and Manitoba have the highest Aboriginal population percentage, each with about 16 percent of the total population in 2011. In Alberta and British Columbia, the Aboriginal population share is roughly 6 percent. Ontario and Quebec have about 2 percent.

Is it possible that such large differences could be a significant factor in weaker results in Saskatchewan and Manitoba? We simply do not know the answer to that question. PISA and PCAP do not include results from on-reserve schools.

As well, PISA assesses students at age 15. We do not know what proportion of students at that age would have spent part of their time in a reserve school and part in a non-reserve public school. We also do not have enough information on the interaction among results in schools, the

16 There have been attempts to measure the relationship between teacher pay and student performance in various American states. These are surveyed in Hanushek (2006) who comes to the conclusion that any evidence linking broad measures of school resources (assuming these translate into teacher salaries) and academic results is weak. However, Loeb and Page (2000) do find evidence that higher relative teacher salaries are associated with lower dropout rates and higher university attendance rates.

17 The online Appendix repeats this analysis with PCAP results for Grade 8 students.

18 Johnson (2006) emphasized social and economic differences across schools to explain about one-half of the variation in Ontario school-level assessment results. 


\section{Figure 1a: Earnings Percentiles of Second Highest Teacher Salaries Relative to All Earners and} PISA Scores

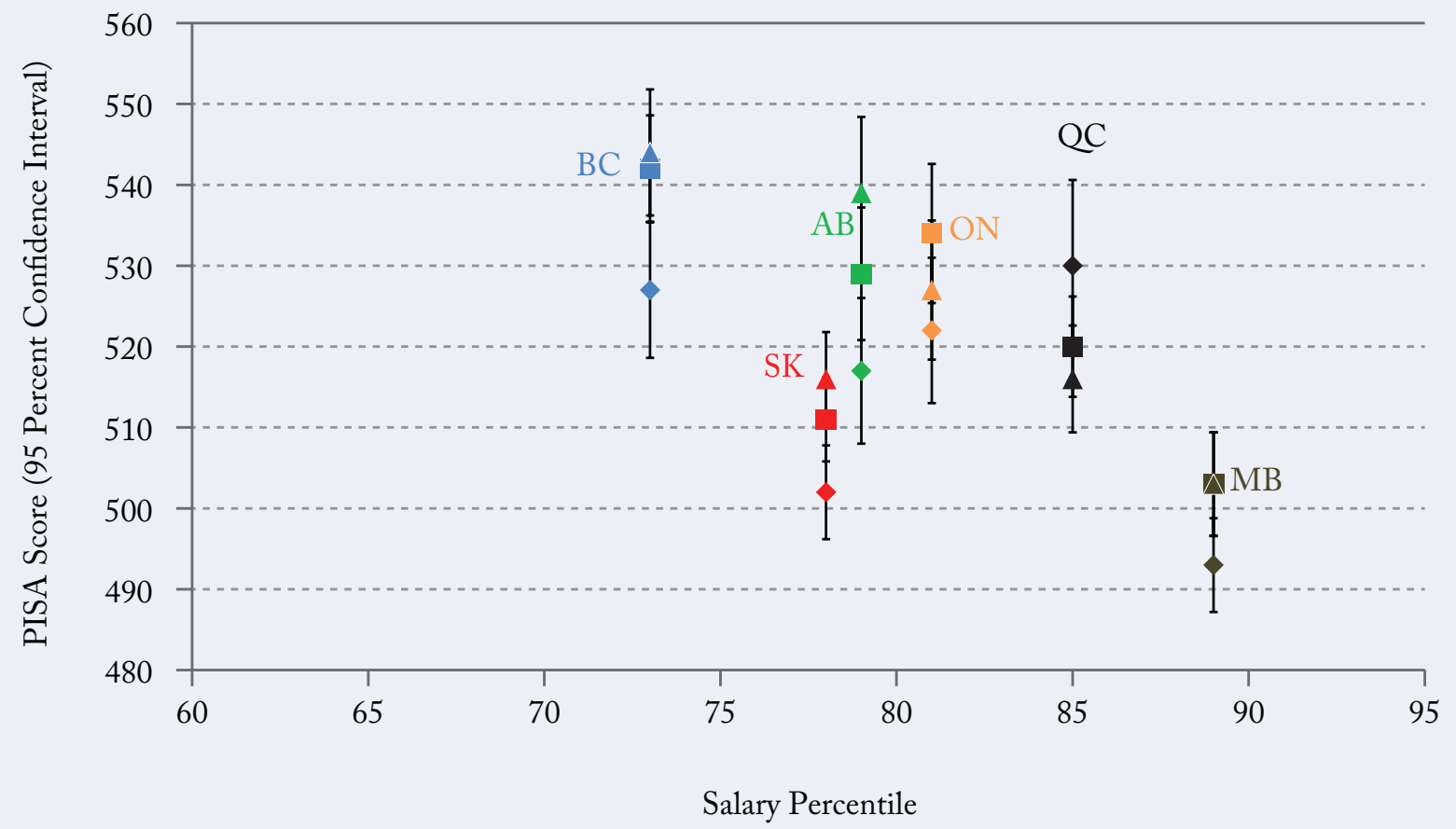

$\diamond$ Math $\square$ Reading $\triangle$ Science

Source: Author's calculations as described in text and online Appendix and Brochu et al. (2013).

educational status of Aboriginal parents and what proportion of Aboriginal students come from disadvantaged economic circumstances.

Figure 3 shows the substantial variation in the share of the population who declare as Aboriginal in the National Household Survey across the six provinces. It is clear that Saskatchewan and Manitoba have the highest percentage of
Aboriginals and somewhat lower PISA results. ${ }^{19}$

However, we can compare like pairs of provinces. British Columbia and Alberta have a similar share of Aboriginals and record similar or better student results than Ontario and Quebec, provinces with many fewer Aboriginals. ${ }^{20}$ Meanwhile, Saskatchewan students usually have stronger results than Manitoba students, although not always

19 Richards (2014) notes that the variation is even more pronounced when the NHS is used to calculate the percentage of school-aged population who are Aboriginal. See the online Appendix for this calculation.

20 Richards (2014) investigates interprovincial variation in Aboriginal school success in more detail. 


\section{Figure 1b: Earnings Percentiles of Highest Teacher Salaries Relative to All Earners and}

\section{PISA Scores}

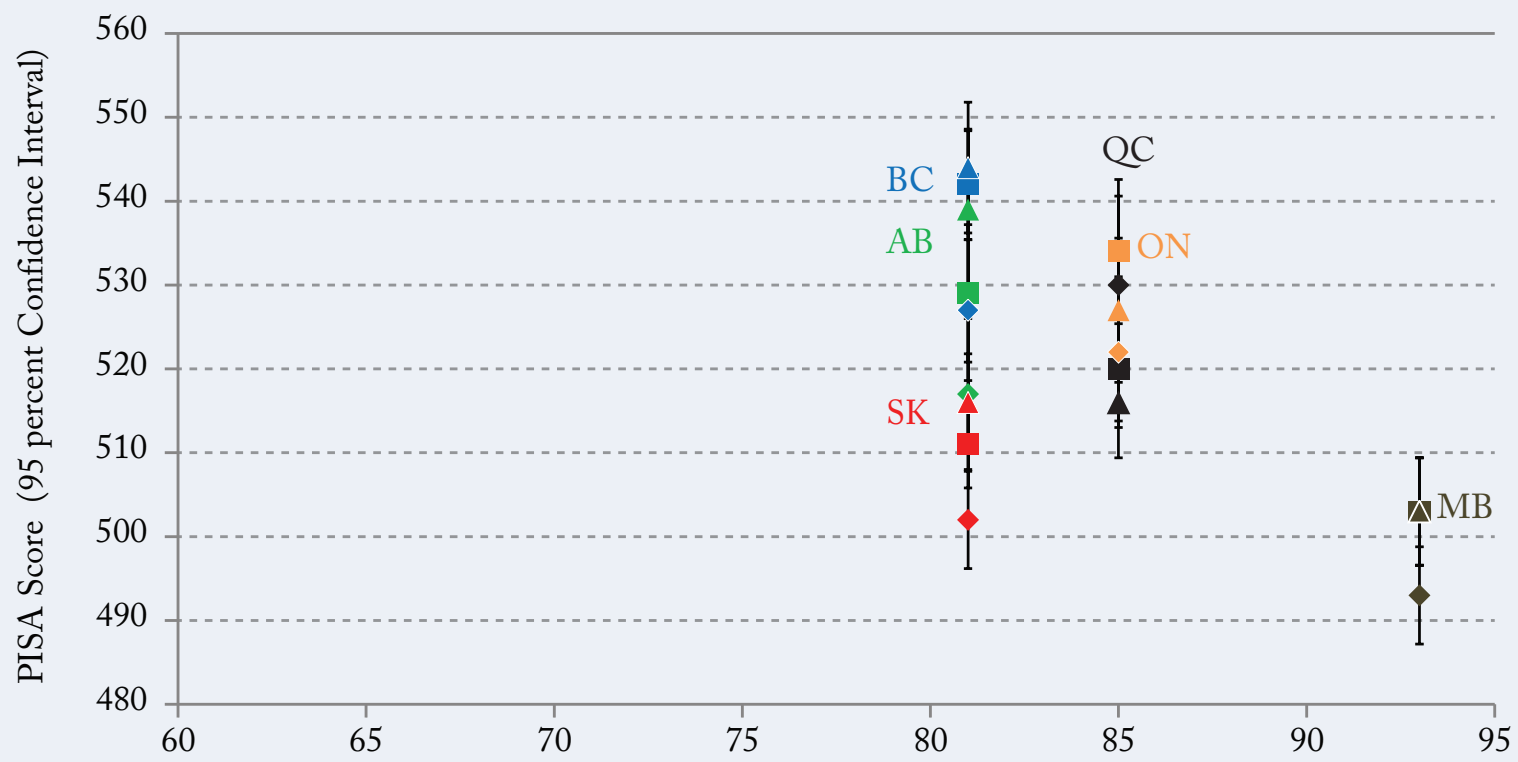

Salary Percentile

$\diamond$ Math $\square$ Reading $\triangle$ Science

Source: Author's calculations as described in text and online Appendix and Brochu et al. (2013).

with statistical significance, despite their similar Aboriginal population percentages. Yet high-pay category Saskatchewan teachers are paid much less relative to their Manitoba counterparts. Indeed, it is important to recall that one-half of Saskatchewan teachers are actually paid considerably less than the pay scales presented in Tables 1,2 and 3. This implies Saskatchewan teachers produce better or the same results than those in Manitoba, even though they are paid considerably less in relative terms. ${ }^{21}$

The second cautionary note in concluding that there is no relationship between teacher salaries and student performance is related to the share of the population with a university education. By province, those percentages are: BC (23.4); Alberta (20.1); Saskatchewan (17.5); Manitoba (18.5); Ontario 


\section{Figure 2a: Earnings Percentiles of Second Highest Teacher Salaries Relative to Non-teacher} Earners with Bachelor's Degrees and PISA Scores

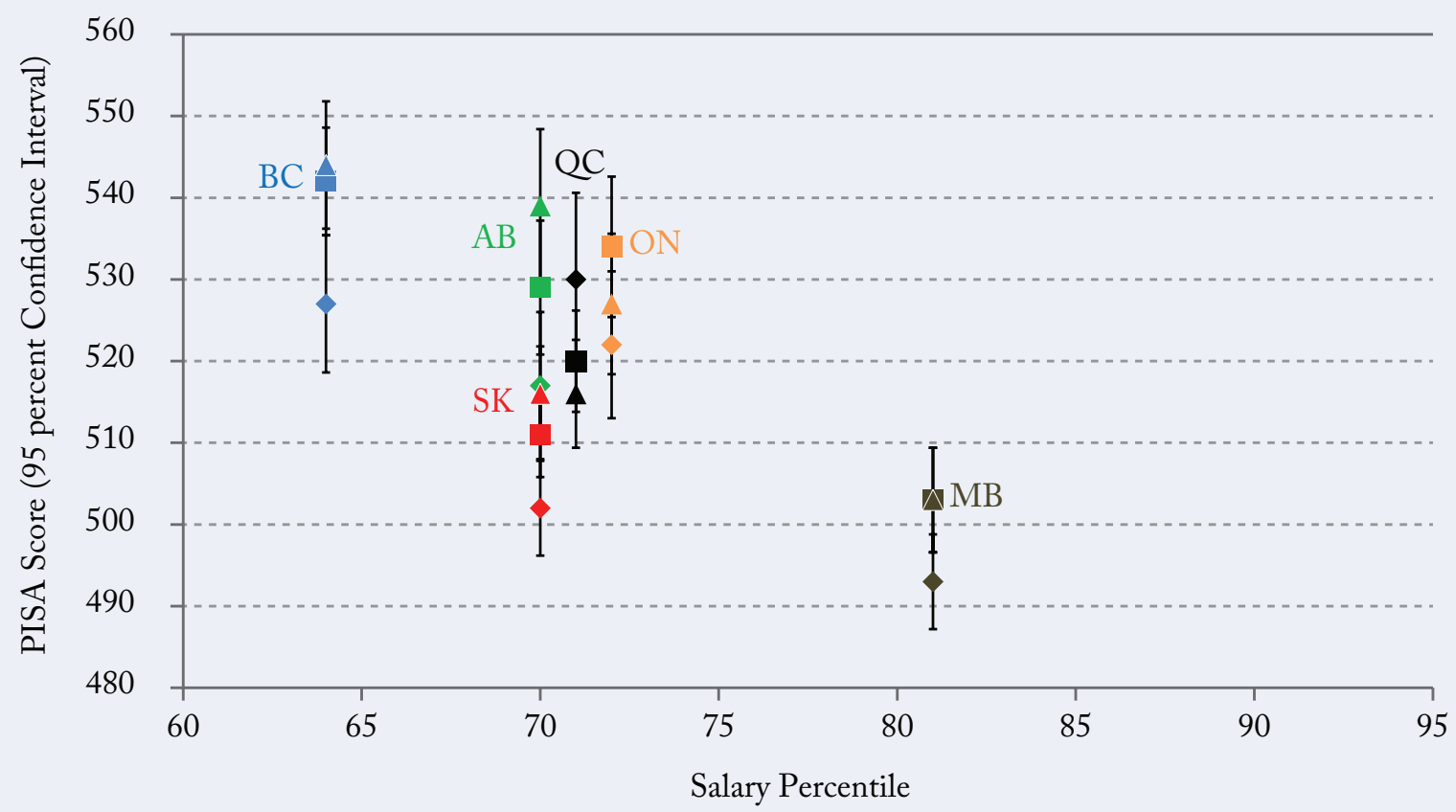

$\diamond$ Math $\square$ Reading $\triangle$ Science

Source: Author's calculations as described in text and online Appendix and Brochu et al. (2013).

(24.5) and Quebec (20.8). ${ }^{22}$ Using these numbers at face value may again partly explain lower achievement levels in Manitoba and Saskatchewan. These are the two provinces with the lowest levels of adult education. This is almost certainly associated with the larger percentage of Aboriginals. Still, Saskatchewan, where fewer people have university degrees and teachers are paid less than in Manitoba, produces better PISA results than Manitoba.

Meanwhile, on the other hand, $\mathrm{BC}$ students, whose parents are only slightly less educated than those in Ontario and whose teachers are paid much less, score similar or better PISA results in all three subjects than those in Ontario. As well, science

22 Again, there is the cautionary note that the Census includes all persons in the province, including Aboriginals on reserves. However, the parents of the students in the schools in the PISA and PCAP assessment groups do not include on-reserve parents. Particularly in Saskatchewan and Manitoba, parents of students at assessed schools may have quite different levels of education and different proportions of Aboriginal status than in the province as a whole. 


\section{Figure 2b: Earnings Percentiles of Highest Teacher Salaries Relative to Non-teacher Earners with} Bachelor's Degrees and PISA Scores

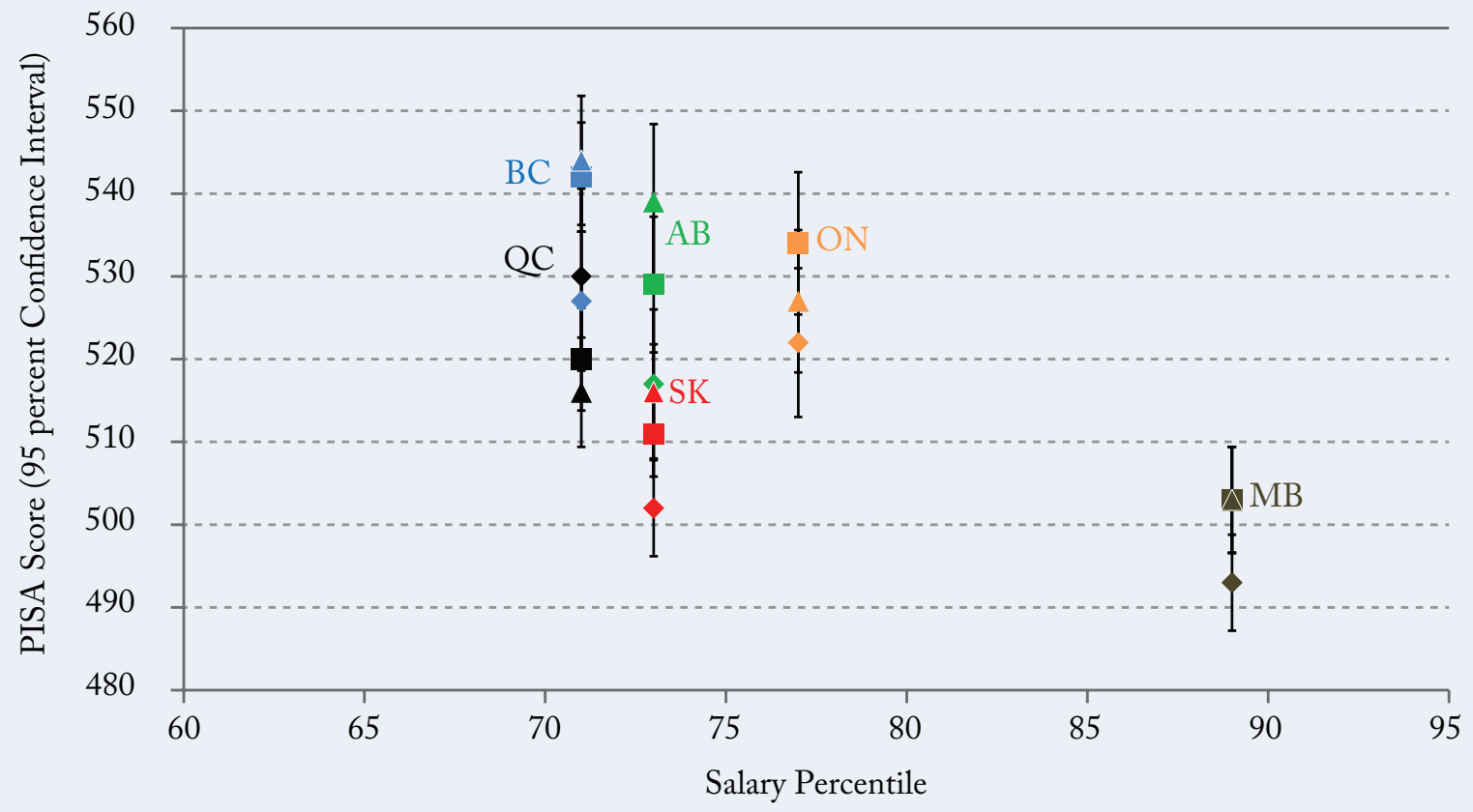

$\diamond$ Math $\square$ Reading $\triangle$ Science

Source: Author's calculations as described in text and online Appendix and Brochu et al. (2013).

results in British Columbia are significantly higher than those in Ontario.

\section{COLLECTIVE BARGAining AND TEACHER SALARIES}

The salaries of public-sector teachers in Canada are determined by collective bargaining. Slinn and Sweetman (2012) edit a very useful volume that examines the current and changing state of collective bargaining procedures for teachers across the country. Is there a common factor in the history of teacher collective bargaining that might explain salary variation among provinces?
One important issue is whether the bargaining on major cost items - salaries, pensions and workload (class size and non-teaching time) - is carried out centrally or locally. Virtually every province except Manitoba has moved to a central (provincial) role on these major issues.

A second theme in teacher labour relations is the movement throughout Canada from a system where some or most of a school's funding depended on the local property tax base to a situation where all money comes directly from the province. Manitoba is the only province among the six where local funding still plays a significant role. 


\section{Figure 3: Aboriginal Population Share and PISA Scores}

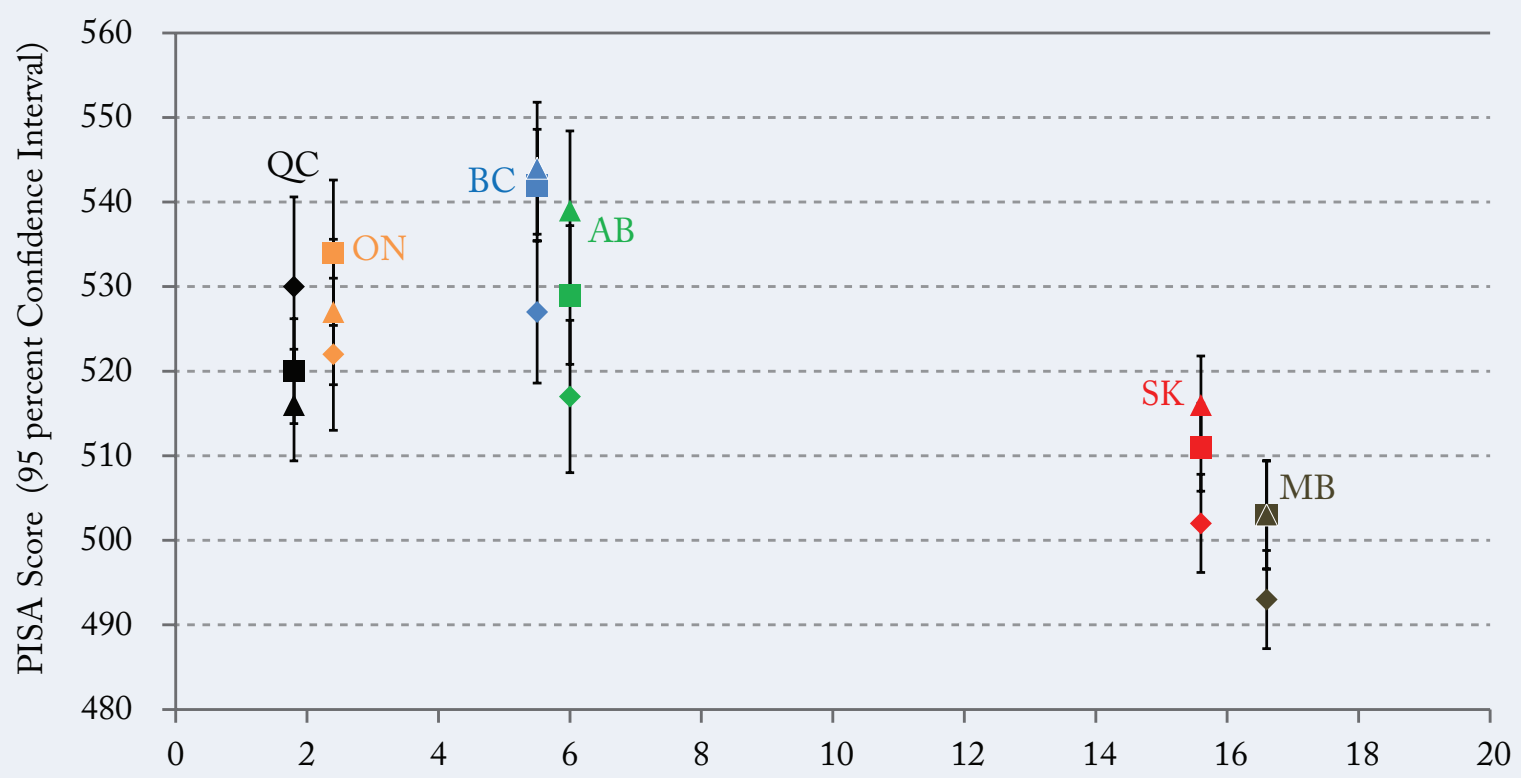

Percent of All Persons who are Aboriginal

$\diamond$ Math $\square$ Reading $\triangle$ Science

Source: Author's calculations from Statistics Canada and Brochu et al. (2013).

The movements to centralize school financing and bargaining as well as the movement that separates schools from local property tax funding are linked but do not coincide with one another. Saskatchewan (since 1968), Quebec (since 1971) and British Columbia (since 1996) have the longest histories of either actual or de facto centralized bargaining. Ontario took away control of the local property tax base from school boards in 1997. Ontario passed legislation formalizing the move of major bargaining items to the provincial table in 2014. Alberta, at least ahead of the 2015 election, was creating a similar law formalizing centralized bargaining.
A third theme in teacher labour relations is the right to strike. Manitoba bans strikes in schools and settles disputes with arbitration. In all other provinces, strikes are legal but often face complicated case-specific restrictions. Many strikes in recent years have in fact been settled by legislation and there is a role for arbitration.

The analysis in this Commentary suggests a different measure of success for collective bargaining in the education field. From the point of view of taxpayers, the most successful collective bargaining is that which obtains the best academic outcome at the lowest price. Although far from conclusive, a proposition that is consistent with 
the evidence in this Commentary is that centralized bargaining over a long period of time would help taxpayers lower the relative cost of teacher salaries without reducing academic outcomes. The only province without any form of centralized bargaining, Manitoba, has the highest relative compensation for teachers. Two of the three provinces with the longest history of centralized bargaining pay lower relative salaries than Ontario and, significantly, do not have lower academic outcomes. The cautionary note here: Manitoba is also the only province with salary arbitration for teachers in place of the right-to-strike.

\section{CONCLUSIONS}

This Commentary comes to two clear conclusions. Public teacher compensation, when measured using relative earnings, shows significant variation across the six largest Canadian provinces. However, comparable student achievement assessment results are not lower in provinces where teachers are paid relatively less. Factors other than teacher compensation that are unexplored here may better explain the interprovincial variation in student achievement results.

The policy implications are fairly clear. There appears to be room to reduce the growth of teacher compensation relative to other occupations so that teachers in other provinces end up in similar salary percentiles to teachers in BC. It would also seem that other provinces could implement much less generous pension rules, emulating those in British Columbia. The BC PISA results suggest that, despite considerably lower levels of overall relative compensation, $\mathrm{BC}$ attracts persons to be teachers who produce high-quality outcomes.

It is unrealistic to expect that such a compensation change could occur quickly in provinces where teacher salaries fall into higher percentiles. Still, relative salaries could be reduced gradually by having a series of wage settlements where increases are less than the rate of inflation. Pension factors could also be adjusted very gradually so that the 85 (or 80 in the case of Manitoba) factor could rise by six months each year for a decade. This would allow an orderly change in retirement plans by teachers. ${ }^{23}$

Saskatchewan and British Columbia, with the longest histories of collective bargaining and centralized funding, are two provinces with clearly lower relative teacher salaries. It seems possible that relative teacher compensation in Alberta and Ontario could gradually fall to the levels in British Columbia and Saskatchewan as these provinces move to a more centralized bargaining process. 


\section{REFERENCES}

Akiba, Motoko et al. 2012. "Teacher Salary and National Achievement: A Cross-national Analysis of 30 Countries." International Journal of Educational Research. 53: 171-181.

British Columbia Teachers' Federation. 2014. "2013-14 Canadian Teacher Salary Rankings: Provinces and Territories." Vancouver. Available at: http://www.bctf.ca/uploadedfiles/public/ bargainingcontracts/teachersalaryrankings201314brief.pdf.

Brochu, Pierre et al. 2013. "Measuring up: Canadian Results of the OECD Pisa Study.” Council of Ministers of Education, Canada. Toronto. Available at: http://cmec.ca/Publications/Lists/ Publications/Attachments/318/PISA2012_ CanadianReport_EN_Web.pdf.

Dolton, Peter, and Oscar Marcenaro-Gutierrez. 2011. "If You Pay Peanuts, Do You Get Monkeys? A Cross-Country Analysis of Teacher Pay and Pupil Performance." Economic Policy 26 (65): 5-55.

Elementary Teachers' Federation of Ontario (ETFO). 2014. Accessed at: www.etfo.ca.

Ellis, Myles, and Richard Riel. 2013. "It's Time to Begin an Adult Conversation about PISA." Canadian Teachers' Federation. Ottawa.

Freisen, Jane, Benjamin Cerf Harris and Simon Woodcock. 2015. Expanding School Choice through Open Enrolment: Lessons from British Columbia. Commentary 418. Toronto: C.D. Howe Institute. February.

Hanushek, Eric. 2006. "School Resources." In Eric Hanushek and Finis Welch (eds). Handbook of the Economics of Education (Vol. 2). Amsterdam: Elsevier.

Johnson, David. 2006. Signposts of Success: Interpreting Ontario's Elementary School Test Scores. Policy Study 40. Toronto: C.D. Howe Institute.
Johnson, David. 2014. A Tale of Two Cities: Learning from Provincial Achievement Test Results in Calgary and Edmonton. Society for Quality Education. Available at http:// societyforqualityeducation.org/reports/ taleoftwocities.pdf.

Leonard, Phil, and Arthur Sweetman. 2014. "Paying the Health Workforce." In Gregory P. Marchildon and Livio Di Matteo (eds). Bending the Cost Curve in Health Care: Canada's Provinces in International Perspective. Toronto: University of Toronto Press.

Loeb, Susanna, and Marianne Page. 2000.

"Examining the Link between Teacher Wages and Student Outcomes: The Importance of Alternative Labor Market Opportunities and Non-pecuniary Variation." Review of Economics and Statistics. 82(3): 393-408.

O'Grady, Kathleen, and Koffi Houme. 2014. Report on the Pan-Canadian Assessment of Science, Reading and Mathematics. Toronto: Council of Ministers of Education of Canada.

Organisation for Economic Cooperation and Development. 2012. PISA 2012 Results: What Students Know and Can Do: Student Performance in Mathematics, Reading and Science. Paris: OECD. Available at: http://www.oecd.org/pisa/ keyfindings/pisa-2012-results-overview.pdf.

Makes Schools Successful? Resources, Policies and Practices (Volume IV), PISA, OECD Publishing. Available at: http://dx.doi. org/10.1787/9789264201156-en.

. 2014. (a) "Indicator D3: How much are teachers paid?” In Education at a Glance: OECD Indicators. Paris: OECD. Available at: http://dx.doi.org.10.1787/888933119815. 
2014. (b) PISA 2012 Results in

Focus: What 15-year-olds Know and What They

Can Do with What They Know. Paris: OECD.

Available at: http://www.oecd.org/pisa/

keyfindings/pisa-2012-results-overview.pdf.

Richards, John, Jennifer Hove, and Kemi Afolabi.

2008. Understanding the Aboriginal/Non-

Aboriginal Gap in Student Performance: Lessons

from British Columbia. Commentary 276.

Toronto: C.D. Howe Institute. December.

Richards, John. 2014. Are We Making Progress? Nerw

Evidence on Aboriginal Education Outcomes in

Provincial and Reserve Schools. Commentary

408. Toronto: C.D. Howe Institute. April.

Slinn, Sara, and Arthur Sweetman, editors.

2012. Dynamic Negotiations: Teacher Labour

Relations in Canadian Elementary and Secondary

Education. Montreal and Kingston, ON:

McGill-Queen's University Press.

Woessmann, Ludgar. 2011. "Cross-country

Evidence on Teacher Performance Pay."

Economics of Education Review. 30:404-418. 
NOTES: 


\section{ReCEnt C.D. Howe Institute Publications}

September 2015 Howitt, Peter. Mushrooms and Yeast: The Implications of Technological Progress for Canada's

Productivity. C.D. Howe Institute Commentary 433.

August 2015 Chant, John. Money in Motion: Modernizing Canada's Payment System. C.D. Howe Institute Commentary 432.

August 2015 Poschmann, Finn. "How to Make the World Safe for (and from) Covered Bonds." C.D. Howe Institute E-Brief.

August 2015 Poschmann, Finn, with Aaron Jacobs. "Improving on the CPI: A Proposal for a Better Inflation Indicator.” C.D. Howe Institute E-Brief.

August 2015 Ciuriak, Dan. "Making Free Trade Deals Work for Small Business: A Proposal for Reform of Rules of Origin." C.D. Howe Institute E-Brief.

July 2015 Jacobs, Aaron. “An Opportunity not to be Wasted: Reforming Ontario's Recycling Program.” C.D. Howe Institute E-Brief.

July 2015 Robson, William B.P., and Alexandre Laurin. Adaptability, Accountability and Sustainability: Intergovernmental Fiscal Arrangements in Canada. C.D. Howe Institute Commentary 431.

July 2015 Koeppl, Thorsten V., and James MacGee. Mortgage Insurance as a Macroprudential Tool: Dealing with the Risk of a Housing Market Crash in Canada. C.D. Howe Institute Commentary 430.

July 2015 Robson, William B.P., and Alexandre Laurin. "Drawing Down Our Savings: The Prospects for RRIF Holders Following the 2015 Federal Budget.” C.D. Howe Institute E-Brief.

June 2015 Jenkins, Paul, and David Longworth. Securing Monetary and Financial Stability: Why Canada Needs a Macroprudential Policy Framework. C.D. Howe Institute Commentary 429.

June 2015 Sen, Anindya. "Peak Power Problems: How Ontario’s Industrial Electricity Pricing System Impacts Consumers." C.D. Howe Institute E-Brief.

June 2015 Hamilton, Malcolm. Do Canadians Save Too Little? C.D. Howe Institute Commentary 428.

May 2015 Stokke, Anna. What to Do about Canada's Declining Math Scores. C.D. Howe Institute Commentary 427.

\section{SUPPORT THE INSTITUTE}

For more information on supporting the C.D. Howe Institute's vital policy work, through charitable giving or membership, please go to www.cdhowe.org or call 416-865-1904. Learn more about the Institute's activities and how to make a donation at the same time. You will receive a tax receipt for your gift.

\section{A REPUTATION FOR INDEPENDENT, NONPARTISAN RESEARCH}

The C.D. Howe Institute's reputation for independent, reasoned and relevant public policy research of the highest quality is its chief asset, and underpins the credibility and effectiveness of its work. Independence and nonpartisanship are core Institute values that inform its approach to research, guide the actions of its professional staff and limit the types of financial contributions that the Institute will accept.

For our full Independence and Nonpartisanship Policy go to www.cdhowe.org. 

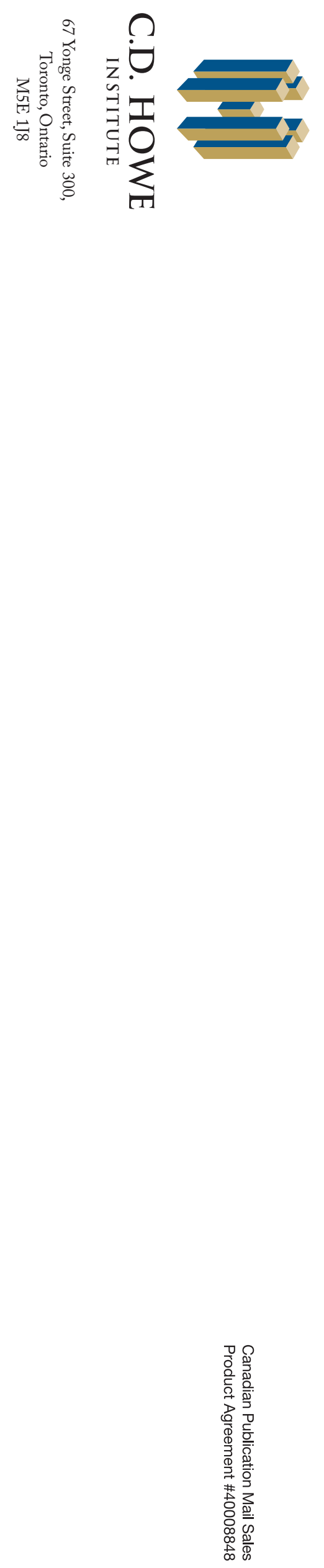